\title{
Subverting Democracy and Thwarting Social Change, an Examination into the Latin American Mass Media
}

\author{
Antonio Castillo* \\ Journalist and Director of Journalism, Royal Melbourne Institute of Technology University (RMIT), Melbourne, Australia
}

\begin{abstract}
In the last few decades Latin America has seen a shift to left leaning, socially progressive and radical governments. Despite their diverse political textures, all of them have been elected democratically and have appealed to the most marginalised sectors of this vast continent. Hand and hand the region has become a fertile ground for the generation, cross-fertilization and consolidation of history-changing socially progressive movements. From the 2011 student movements in Chile, to the recent Bolivian Aymara Indian actions to block the Dakar rally, Latin America is experiencing a rich tapestry of energetic citizen movements. Considering these two contemporary paradigms, one could argue that Latin America is going through a process of democratic engagement from below. It is a political and civil movement instigated and led by grassroots urban and rural actors struggling to achieve a truly democratic system, a democratic system where social, economic, cultural and environmental justice prevails. The struggle is not without its foes. There is one deep-rooted foe that since the post-colonial period has tried to preserve its class privilege, economic interest and economic control. The Latin American right is not exempt from mighty tools to subvert democracy and obstruct social change. And the mass media is one of its most formidable. In a broad and big-picture approach this article examines, contextualizes and brings up-to-date the role the mass media plays as an "ideological organizer" of the Latin American right. In this context, this paper gives a special emphasis to Chile's El Mercurio, considered the country's "paper of record." It is the oldest daily in the Spanish language currently in circulation and it is the archetypical media "ideological organizer" of the right. Its role in subverting democracy and suppressing social progressive movements cannot be underestimated.
\end{abstract}

Keywords: Social movements; Latin America journalism; Latin America media; Social movements and media; Democracy and media; Radical democracy; El Mercurio

\section{Introduction}

Latin American's struggle for radical democracy in the context of global capitalism-can't be understood without looking at the role played by the vital ideological organizer of the right, the mass media. The wisdom of history might allow us to suggest that Latin American mass media has been the most formidable enemy of radical democracy and progressive movements. To say that the mass media has a democratic deficit, as some have mildly suggested, is an understatement. The mass media-from Mexico in the north to Chile in the south-has been profoundly undemocratic and ideologically conservative. It has been an almost unchallenged ideological apparatus for the preservation and protection of the right's class interest, economic power and political hegemony. Historian Ralph Miliband was not wrong when he observed that the mass media was an expression of a system of domination and a means to reinforce it (2013). The mass media-he pointed out-is characterised by a "passionate hostility to anything further to the left."

\section{Radical democracy and social movements}

One of the most noticeable political changes Latin America experienced in the last few decades has been the generation and consolidation of radical democratic governments led by the left. And while they have similar and also different characteristics, the common and shared underpinning goal is the radicalization of democracy, the establishment of a more equal society and the defeat of poverty. It is intriguing this happens in a region that a few decades back was largely under the iron and criminal fist of military dictatorships and was experiencing a sluggish transition to democracy. Intriguing is also the fact this has been occurring in the context of an aggressive, overconfident global capitalism. When in 1999 the late president Hugo Chavez reached power for the first time and dismantled the archaic and corrupt old system in Venezuela, large swathes of the region began "swerving left" [1]. It was-as Castañeda points out-a backlash against decades of neoliberal and free market reforms. It was also a backlash against a representative democratic system that neglected the many, the poor; and stood for the fewer, the elite. The state-almost annihilated by the conservative forces-began taking on different roles. Some were urgently needed, such as povery reduction, educational reforms and empowerment of the poor, the indigenous and other historically excluded social actors. The election of Chavez in 1999 was followed by the election of-among others-Luiz Inácio Lula da Silva, in Brazil, Nestor Kirchner and Cristina Fernández in Argentina, Tabare Vásquez in Uruguay, Evo Morales in Bolivia, Michelle Bachelet in Chile, Ollanta Humalla in Peru, Alvaro Colom in Guatemala, Daniel Ortega in Nicaragua and Rafael Correa in Ecuador.

Most of these governments came to power with presidential and congressional majorities, allowing them to introduce far-reaching public policy measures. And when it comes to the media a few of themespecially Hugo Chavez, Evo Morales, Cristina Fernandez, Rafael Correa and Ollanta Humala, have taken the mass media on. These governments have put in place the public policy that Nobel winner Joseph Stiglitz called "good media governance" [2]. In a 2013 World

*Corresponding author: Antonio Castillo, Journalist and Director of Journalism Royal Melbourne Institute of Technology University (RMIT), Melbourne, Australia, Tel: +61-3-9925-2000; E-mail: antonio.castillo@rmit.edu.au

Received January 20, 2014; Accepted March 04, 2014; Published March 31 , 2014

Citation: Castillo A (2014) Subverting Democracy and Thwarting Social Change, an Examination into the Latin American Mass Media. J Mass Communicat Journalism 4: 185. doi:10.4172/2165-7912.1000185

Copyright: @ 2014 Castillo A. This is an open-access article distributed unde the terms of the Creative Commons Attribution License, which permits unrestricted use, distribution, and reproduction in any medium, provided the original author and source are credited. 
Bank Latin American media symposium, Stiglitz-who hardly can be called leftist-spoke against media concentration and monopolies and stressed that good media governance helps to overcome inequality. He also criticized the lack of media diversity, access to information and advocated a communication media that gives a voice to all types of people and helps reduce inequalities. Sergio Jellinek, World Bank Manager of External Affairs for Latin America, used similar concepts on the same subject. He stressed the importance of a media system that is plural in terms of content, vision and ownership. Jellinek advocated for a media that ensures more participation of public opinion in development processes and involves citizens in decision-making. The late Hugo Chavez couldn't have put it better. After the long and painful interregnum of military dictatorships, a reinvigorated social movement has accompanied the arrival of left leaning governments. Either supporting or rejecting the work of the state, this movement has been reshaping the political landscape of the region and has become the basis of radical democracy. The basis of this radical democracy has been the profound critique of the neoliberal economic policies that have caused so much pain in the region. Towards the end of the 1990s and early 2000s- a period of economic crisis and when the neoliberal pillages throughout Latin America reached its paroxysm [3]-the popular discontent paved the way for major social movements.

In Brazil, the Rural Landless Workers Movement (MST), with over 300,000 members and over 350,000 peasant families settled in cooperatives throughout the country. It represented the largest and bestorganized social movement in Latin America. In 2013, an emerging street-urban movement began shaking the government of President Dilma Rousseff. In Colombia and Chile the educational system has been at the centre of one of the most active social movements in the region. Students and teachers in Colombia took to the streets of the major cities in protest against the so-called Law 30 that if passed would allow the privatisation of public universities. In Chile-since 2011-the student movement has been demanding an overhaul of the education system. In Bolivia, a country with one of the most active social movements in Latin America, indigenous communities have marched to oppose President Evo Mora le's controversial project to build a road that would go through the Isiboro Sécure Indigenous Territory National Park. And early in 2014, indigenuos communities threatened to block the Daka rally for its potential damage to the environment in the Altiplano of Bolivia.

In Argentina the mass protest of December 2001 in Buenos Airesthat caused the end of the government of President Fernando de la Rúa- became the seed for further social movements. One of them has been the movement for the democratization of the media system. President Cristina Fernández has been unmoved in her aim to break the media concentration and monopoly. In Ecuador, the National Confederation of Indian and Nationalities in Ecuador (CONAIE) played a central role in the overthrow of two neo-liberal Presidents, Abdala Bucaram in 1997 and Jamil Mahuad in January 2000, implicated in massive fraud and responsible for Ecuador's economic crisis of the 1990's. The indigenous movement in Chile has been active in the face of increasing police repression. Several of its leaders are languishing in jails and others are on life threatening hunger strikes. The demand for land rights and environmental justice has fallen on deaf ears. It seems the only listening is done by the mass media that have constructed themas terrorists and their actions as deviant. The most effective ideological organizer of the right, the mass media, has not been silent either on the face of elected left leaning governments or on the face of actively engaged social movements. Far from silent, the Latin American mass media have continued playing its ideological role of defending the interests of its propietors and those of the private sector.

\section{The media at the center of the public debate}

The advent of progressive governments and the blossoming of the social movements in Latin America have been accompanied by an intense debate on the mass media system and its role in this new context. As Mc Chenesy pointed out, media policy is -along with education-central to debates over the nature of democracy (2000). Those who hold the power "write history" was the dictum of Plato; and those who control the media control the voice of the nation. And the "voice" in Latin America has been for a very long time monopolized and controlled by the commercial mass media. This trend has a political context-the election of several progressive governments in the region. These governments-Argentina, Ecuador, Bolivia and Venezuela among others-advocate profound changes to the commercial oligarchic media system while at the same time they have been developing their own media strategies and institutions and in this process conflict is inevitable. These leaders have identified the commercial media as a principal obstacle to their efforts to transform the region until recently these monopolies had nothing to worry about. Not any longer. The bitter struggle waged by the government of Cristina Fernández to reform the Argentinean broadcast system-in other words to break the media monopoly is one example. In 2009, President Fernández proposed a bill that would reform the broadcast law in place since the last military dictatorship. In Argentina this debate has polarized society. In 2010 President Cristina Fernández took a major step when she sought to take control of the country's only newsprint maker [4]. It is the only company able to produce newsprint in the country and had been under the control of El Clarín and La Nación, the two most powerful media groups in the country, since the military dictatorship. In Argentina, the ley the comunicación audiovisual (audiovisual communication law) aimed at breaking the media monopolies. The law cuts the number of radio and television licenses a single owner possesses from 24 to 10. Fundamentally the law forces Argentina's largest media groups to sell off various radio and television channels. In 2012, in October, this law was approved in congress. However, it was challenged in the judiciary by the right wing opposition and the owners of the media monopolies, most of them associated with the last dictatorship. The law is at the moment in the Supreme Court and has been one of the major issues of public debate in Argentina. It has been widely supported by progressive political forces, unions, grass roots organizations and students. Even the legendary Mothers of the Plazo de Mayo have supported this media reform.

This law was also applauded by the United Nations freedom of expression Special Rapporteur and has been supported by universities. In April 2013, there was a massive gathering of people-around 50 thousand-who marched from the Congress to the Palace of Justice demanding the application of the law. In addition, President Fernández has attempted to remove the power of the commercial media by giving preference to sympathetic media with the lucrative government advertising. Página 12, a quality newspaper closed by the current government has received more state paid advertising than other publications with larger circulation. The distribution of government advertising is one way to boost sympathetic media. Nicaragua's Daniel Ortega replicates what Cristina Fernández is doing in Argentina with Página 12. Since taking office in 2007, Ortega has imposed a de facto advertising embargo on critical media while rewarding the official press. It is clear though this is a strategy to marginalize the influence of business. In an interview to Al-Jazeera, Ortega told David Frost that Nicaragua is fighting "a media war, war of ideas." 
According to a report, the government spent 80 percent of its US $\$ 3.5$ million advertising budget in 2007-2008 for spots on Channel 4. This is a television channel run by Ortega's sons. Isolation and marginalisation of the critical media have become the key strategy of Daniel Ortega. He and his officials maintain contact with only a handful of pro-government outlets controlled by the president's family of his party. Even with these outlets doesn't grant interviews, relying instead on sympathetic journalists to publish his prepared statements and cover his public events. This strategy is not limited to left wing governments though. According to a 2008 study-"The Price of SilenceThe Growing Threat of Soft Censorship in Latin America" by the Open Society, between 2005 and 2007, the former government of Álvaro Uribe in Colombia, gave to La República-a newspaper with small circulation-"frequent and suspiciously high financial installments." The distribution of government advertising takes-on some occasionsthe form of a contract with individual journalists. In Honduras there are contracts with clauses that oblige journalist to interview specific officials. The contract ends as soon as the coverage is critical of the official. In Chile the most powerful media organizations- print and electronic-are controlled by the financial and political oligarchy. There are a small number of family-owned companies whose financial power was consolidated thanks to the military regime. This is the case of $\mathrm{El}$ Mercurio and La Tercera newspapers in Mexico, Brazil and Colombia. Mexico's Televisa and Brazil's Globo-in private hands-emerged and expanded with the help and protection of the right wing authoritarian regimes of the 1970s and 1980s. In Colombia massive media groups are controlled by a few rich families and muffle criticism of Colombian leaders, who mostly have represented the right of the political spectrum.

The media and political struggle in Venezuela is perhaps the best example of this struggle for the media system. The late Hugo Chavez used his charisma to establish a direct communication with his supporters and also enhanced the official media apparatus, introducing a new regulatory framework for the private and commercial media which is subject-in addition-to a permanent political and legal harassment case. The media and political conflict in Venezuela has been replicated-perhaps less virulent-in Bolivia, Ecuador and Nicaragua. Paradoxically in Chile, the governments of the post-dictatorship have opted for a non-media policy approach leaving the media to the market. It has been a bizarre state of affairs in Chile, where all the prodemocracy print media that emerged during the military dictatorship was unable to survive in democracy. And the democratic governments didn't do anything to save them. The lucrative state advertising sector was-and still is-syphoned to El Mercurio and La Tercera. Breaking the hegemonic power of the mass media has been at the heart of the media debate in Ecuador and Peru. Ecuador's president Rafael Correa also shares this media war perception. He described the media as his "greatest enemy." He has denounced journalists as "corrupt, mediocre and shameless." And Peru's president Humala has begun an offensive to break the extraordinary media monopoly of Grupo Comercio. It controls 80 percent of the print press, a situation that according to the Nobel Prize winner Mario Vargas Llosa is a serious threat to freedom of opinion and democracy (2014).

\section{Ideological minders and organizers}

History has the power to place things in context. In the situation where the media has become a political battleground-as The Guardian's Rory Carroll put it (2010)-it's important not to forget that the mass media is a formidable minder and organizer of the Latin American right. And there is lot to remember and learn from the lost battle waged by Chilean Socialist President Salvador Allende against the commercial mass media, 1970-1973. During the government of the Unidad Popular the Chilean media increased significantly in importance as a social and political actor. The presidential election of 1970 was the first political contest in Chilean history fought within a media landscape characterised by the increasing popularity of television. The communication debate about popular access to the media deepened and reached a level of crisis during the three years of the Socialist government of President Salvador Allende. Although Allende denounced foreign influence in the media and the financial and ideological monopolistic hegemony, he was unable to offer an alternative to the bourgeois communication structure. Political polarization and social conflict had exhausted any possibility of agreement on media management. In an increasingly mediated political scenario, Allende faced a central dilemma: what to do with the media in the context of the Chilean road to socialism. During the three years of socialist government, the unresolved dilemma of the Unidad Popular was to find an alternative to the right wing hegemonic media system in Chile. President Allende faced the challenge of ruling within a media and cultural landscape mainly dominated by a politically conservative social class. The wealthy bourgeoisie owned most of the mainstream media. Prior to his election, Salvador Allende was an enduring critic of the effects of private and foreign ownership of the Chilean media. However, when the Unidad Popular finally reached power he was incapable of offering an alternative media policy to modify the monopolistic and commercial nature of the Chilean communication system. This was despite the importance given by the Unidad Popular's political program to the role of the media. The rest of the story is well known. El Mercurio group, the owner of the oldest Spanish language newspaper in Latin America El Mercurio, was one of the key tools used to destabilize and finally end the government of President Allende. Since its foundation in 1827, El Mercurio has been considered the ideological organizer of the right per antonomasia. Declassified documents that detail the US intervention in Chile revealed the newspaper's role and the extent of its cooperation with the CIA. El Mercurio received funds from the CIA in the early 1970s to undermine the Socialist government of Salvador Allende, acting as mouthpiece for anti-Allende propaganda. More than forty years have passed since then and El Mercurio continues-now in democracy-its role as the key ideological bastion, defender and promoter of the conservative views of the right. Further it has continued its role-just like in the 1970s-as an anti- progressive voice against the centre-left governments that with the exception of 2010-2013 have governed Chile.

El Mercurio has effectively exercised an ideological dictatorship without parallel. It has been successfully able to influence Chilean political leaders-even from the centre left-of the benefits of the neoliberal economic model and the current institutional and constitutional arrangements. In fact the political model of a democracy of low intensity and the brutal neoliberal economic model left in place by the former dictator General Pinochet have not been altered.

\section{Ideological organizer}

"Chilenos: El Mercurio miente" was a phrase coined on August 1967 when, in the middle of university reform at the conservative Catholic University of Chile, a group of students from this gigantic university hung a banner in the front of the university headquarters in downtown Santiago with the phrase "Chileans: El Mercurio lies." It was the now iconic response by the students against the newspaper's attacks against the student movement, characterized by El Mercurio as a "Marxism's new and risky plot on democracy [5]. More than forty years have passed since this iconic moment and nothing has changed. El Mercurio has continued its role as one of the most effective de facto 
instruments of the Chilean right. It is the leading ideological force able to subvert democracy, stall social change and demonize progressive social movements. This time around is the turn of the Chilean student movement that since 2011 has shaken the political and social sphere in a country that is still marked by a profound democratic deficit and economic inequality. The student movement-that has had a national and international impact-began as a critique of the educational system that was characterized as mediocre and highly discriminatory and soon moved to a public rejection of the neoliberal economic model. This is the model introduced by former dictator General Pinochet (1973-1989) and maintained utterly unchanged by the governments of the transition to democracy [6]. Social and political protests have been an important part of Latin American political culture and have helped to shape the course of the region. And the student movement occupies a central part in the history of protests. However, they have been fiercely fought by the mass media. In light of Di Cicco's Nuisance Paradigm- a tendency of the mass media to represent social protests as "troublesome, unpatriotic and ineffective" (2000: 13)-El Mercurio has resorted to the same media strategy that it used to discredit the student movement of 1967. The coverage of the student movement was constructed since its early days as a violent conflict attempting to subvert the democratic process and the economic model. Hand in hand with the defence of the democratic model-deeply undermined by the unchanged Pinochet's Constitution of 1980-El Mercurio has been actively engaged in defending the neoliberal model and emphasising the superiority of private over the public, in schools, hospitals, media, etc. In the context of the "nuisance paradigm," El Mercurio tends to favour the perspectives of the political elite and authorities over those of the students, very often excluding their voices entirely. The student claims for better education was constructed as an assault on institutionalization and the street protests were characterized as acts of vandalism. A classic example of "nuisance paradigm" meets "moral panic. El Mercurio-that has maintained its economic power thanks to the generous advertising financial injection given by some of largest economic groups in Chile-has resorted ad nauseam to the fear induced "not to return to 40 years ago" editorial line. It is an indirect and coarse allusion to the Socialist government of President Salvador Allende. Some level of sophistication has been used though. El Mercurio's news agenda is full of "neoliberal newspeak" [7] where concepts such as neoliberal terms-such as "flexibility," "efficiency"-become commonplace in the cultural production of ideas and beliefs. Perhaps one of the most emblematic social movements in Chile is the indigenous Mapuche strugge. At the centre of the Mapuche demands are recognition of their culture, identity and land. They have been pushed to the margins of society and their ancestral land has been occupied by hydroelectric and forest companies. In Chilean history Mapuche resistance against the Spanish conquest is legendary. School children learn of the heroic actions of Mapuche leaders-such as Lautaro and Caupolican-who died resisting the Spanish invaders. They became mythical figures in the Chilean history books. Not any longer. Today, Mapuche resistance has been criminalized and construed as terrorism. "From seventeenth century resistance heroes against Spanish conquistadors we have become twenty first century terrorists," said Arturo Millahual. "We are not terrorists but we are tired of waiting and the actions of resistance will not stop until the government answers our demands," he said Castilo [8].

Carlos Peña an influential public opinion writer said that the forthcoming Chilean bicentenary independence celebrations had the potential to accentuate the conflict. "One century of policies of indigenous forgetfulness has been accompanied by a complete negation of their existence," he said. "The Mapuche identity has been negated and therefore the conflict will not end" [8]. The government-or to be more precise all the post-military democratic governments, from 1990 to today-have systematically failed to responded to the legitimate demands of Mapuche people. And El Mercurio has played again a central part in constructing the indigenous movement as a threat to the political and economic establishment. As Andrea Amolef's study shows, El Mercurio has become the most copious information medium when it comes to the so-called "indigenous conflict" (2004). El Mercurio newspeak refers to the Mapuche actions-sometime expressed in acts of rural and urban violence-as establishing in Chile a "true state of war." El Mercurio's coverage of the indigenous problem in Chile goes a long way back the XIX century when El Mercurio de Valparaiso, the precursor of El Mercurio; and the newspaper El Ferrocarril de Santiago demanded from authorities to take over Mapuche land by force [9].

The contemporary indigenous newspeak constructed by $\mathrm{El}$ Mercurio is not different from the newspeak of the XIX century. Using refined linguistic resources; this newspaper has echoed the voice of the most powerful economic groups-deeply involved in the exploitation Mapuche's land-calling for mano dura (iron fist) against indigenous people. In light of the "nuisance paradigm' mentioned earlier in this article, in the production of stories about this conflict, El Mercurio resorts mainly to official sources and to representatives of the large economic groups. As Amolef contends, the journalistic narrative of this newspaper does nothing more than convey the ideological views maintained by the Chilean right on the demands of the Mapuche people. It is also the case that this narrative becomes handy for the political elite to justify the deployment in highly armed police and even military personnel in the zone of conflict, in the Chilean southern region of La Araucanía.

\section{Breaking democracy}

El Mercurio not only lies but it also has become a model to follow by other Latin American mass media in its attempt to subvert democracy and suppress the actions of socially progressive leaders. Perhaps one of the most dramatic examples of this was the media operation against the late Venezuela's president Hugo Chavez. Writing about the 2002 failed "media coup" against Chavez, I argued that these actions had all the traces of the El Mercurio's campaign against President Salvador Allende. From the time Chavez came to power for the first time in 1999 , Venezuela's commercial mass media was unflagging in its anti-media propaganda campaign. "Never even in Latin American history has the media been so directly involved in a political coup," wrote Le Monde's Maurice. If the electronic mass media, especially television, has become the priviledged space for politics-as Castell and Cardoso suggests $[10,11]-$ one has to say that Venezuela's television has become the space of political sedition. The contribution of the CIA in the 2002 "media coup" has not been totally established. What has been established though is that the US State Department has been funnelling millions of dollars to Latin American journalists, according to US investigative journalist Jeremy Bigwood [12]. A writer for the Huffington Post, Bigwood obtained documents under the Freedom of Information Act (FOIA) that:

"Show that between 2007 and 2009, the State Department's littleknown Bureau of Democracy, Human Rights and Labor channeled at least \$4 million to journalists in Bolivia, Nicaragua, and Venezuela through the Pan American Development Foundation (PADF), a Washington-based grant maker that has worked in Latin America since 1962. So far, only documents pertaining to Venezuela have been released. They reveal that the PADF, collaborating with Venezuelan NGOs associated with the country's political opposition, has been 
supplied with at least $\$ 700,000$ to give out journalism grants and sponsor journalism education programs."

\section{As Bigwood points out:}

"Although the $\$ 700,000$ allocated to the PADF, which is noted in the State Department's requirements document, may not seem like a lot of money, the funds have been strategically used to buy off the best of Venezuela's news media and recruit young journalists. This has been achieved by collaborating with opposition NGOs, many of which have a strong media focus."

The great Uruguayan writer Eduardo Galeano used to speak of "la dictadura de la imágen unica" (the dictatorship of the uniform image), an image that attempts to hegemonize society aroud one vision of society. It is an undemocratic image that progressive governments in the region have been challenging. Bolivia President Evo Morales spoke of the necessity to de-colonise the way the media is managed in order to guarantee the process of social change and Argentina's president Cristina Fernández is engaged in a vigorus fight to break the monopoly of the powerful El Clarín and La Nación media groups. The democratization of the media in Argentina has been emulated by Ecuador's President Rafael Correa who in 2013-June 14-obtained the parliamentary majority that allows the equitative distribution of radio and television frequency-33 percent for the private sector; 33 percent for the public service; and 34 percent for the community media. The new media law defines the media as "a public service that must serve with responsibility and worth." Calls for the democratization of the media have spread across and along Latin America, it is a call to break with the unidirectional, monotonous and monological media discourse. It is a call to reform a system that is not serving the people. The case of Uruguay is graphic. A country that has one of the most progressive social policies in the world is still under a media system ruled by a 1978 dictatorial decree. It is a decree that has allowed that multinationals to own nearly 90 percent of the media.

\section{Conclusion}

"Whoever controls the media, controls the mind"-and no, is not a scholar's quote. However, Jim Morrison, the legendary lead singer of the rock band The Doors-was spot on. And who could argue against him when looking at the Latin American mass media landscape. The non- democratic monopolistic mass media concentration in Latin America has seriously damaged the societal tissue of a region defined by poverty, inequality and exclusion. The Latin American hegemonic mass mediathe organizers of the right and the ideological underpinning of the conservative elite-has led the privatization of life in all its forms. As Barbero points out-privatization of life has become the outcome of the neoliberal project, a project that caused growing inequality, income concentration, reduction of the social expenditure, slimming of the public sphere and the deterioration of cultural and social cohesion (1999:45). "In the past the state and the private elite had the media to humiliate us, for defending their business, their industries or the ownership of the land, for this they have the media," President Evo Morale's-the first indigenous president of any nation in Latin Americamoaned once. And yet, despite his efforts-and the efforts of many other progressive leaders-to democratize the media, this is still a work in progress.

\section{References}

1. Castaneda JG (2006) Latin America's Left Turn. Foreign Affairs. May 1.

2. World Bank (2013) Free press, pluralism and democracy: Media challenges in Latin America.

3. Petras J (2013) Latin America: Social Movements in Times of Economic Crises Venezuel analysis.

4. Merco Press (2010) Argentine government accuses Clarín and La Nación of conspiring with military regimes.

5. Araya P (2008) El Mercurio Miente siete notas sobre escrituras expuestas Revista Austral de Ciencias Sociales 14: 157-172.

6. Castillo A (2009) Journalism in the Chilean Transition to Democracy: The Lost Decade (1990-2000).

7. Bourdieu P, Wacquant $L$ (2001) NewLiberalSpeak, notes on the new planetary vulgate. Radical Philosophy 105: 1-4.

8. Castillo A (2008) Chilean Mapuches, from indigenous mythical heroes to terrorists. Refugee Transition 20: 14-17.

9. Amolef, Andrea (2004) La alteridad en el discurso mediático: Mapuches y la prensa chilena II. Boletin IPF 7: 19-22.

10. Lemoine M (2002) Venezuela's press power. Le Monde Diplomatique.

11. Castell M, Cardoso G (2005) The Network Society From Knowledge to Policy Washington, DC: Johns Hopkins Center for Transatlantic Relations.

12. Bigwood J (2010) Buying Venezuela's Press with U.S. Tax Dollars. NACLA. 